\author{
(online) = ISSN $2285-3642$ \\ ISSN-L = $2285-3642$ \\ Journal of Economic Development, Environment and People \\ Volume 2, Issue 1, 2013 \\ URL: http://jedep.spiruharet.ro \\ e-mail: office jedep@spiruharet.ro
}

\title{
How Does the Changing Access to Resources Affect the Power and Authority of the Postsocialist Romanian State?
}

\author{
Madalina Epure \\ e-mail: M.Epure@uea.ac.uk
}

\begin{abstract}
In the past two decades, former postsocialist countries such as Romania have experienced very radical changes in terms of government and resource policy (Swinnen, 1997; Swinnen et al., 1997; Szelenyi, 1998; Turnock, 1998). To make sense of these changes this review paper will make use of recent postsocialist literature, which links the access and control over resources to the exercise of power and authority in the postsocialist state (Berry, 1993; Lund, 2002; Verdery, 2002; Ribot and Peluso, 2003; Sikor, 2006; Sikor and Lund, 2009; Sikor, Stahl and Dorondel, 2009).

The review paper aims to re-trace this line in postsocialist thinking in the relevant literature and show how the concepts of property and access to resources are connected to the crucial concepts of power and authority. It will perform a critical review of the relevant literature and also explore the aforementioned concepts of property, access, power, authority and state.

It will furthermore show how these concepts feed into the formation and consolidation of the Romanian postsocialist state. Since conflicts over property are emphasised by postsocialist researchers (de Waal, 1996; Giordano and Kostova, 1996; Verdery, 1999; Rabinowicz and Swinnen, 1997; Swinnen and Mathjs, 1997; Szelenyi, 1998; Sikor, 2003; Sikor, Stahl and Dorondel, 2009; Dorondel and Sikor, 2009), these are underlined here and thought to be the main thread connecting property and access to resources with power and authority in the new state. More specifically, the paper will reveal how said conflicts force actors to seek the authorization of their property claims at the door of the state. By doing so, they grant the new state the authority to do so again in the future and thereby contribute to the consolidation of its legitimacy.

Essentially this review paper argues that changes to resource access engender conflicts, which in turn lead to the formation of a new social contract between the postsocialist state and its people (Lund, 2002).
\end{abstract}

Keywords: postsocialism, resources, property, power, authority and the state

JEL Codes: K11,P26, P28, P 36 


\author{
(online) $=$ ISSN $2285-3642$ \\ ISSN-L = 2285-3642 \\ Journal of Economic Development, Environment and People \\ Volume 2, Issue 1, 2013 \\ URL: http://jedep.spiruharet.ro \\ e-mail: office jedep@spiruharet.ro
}

\title{
1. Introduction
}

The demise of socialism in Central and Eastern European has signified the waning and decentralization of state power (Sikor, 2003). In the past two decades, countries here have experienced a radical shift in resource governance, away from that of the previously dominant legal and administrative hierarchy of socialism towards that of markets (Swinnen, 1997; Swinnen et al. 1997; Sikor, 2003; Sikor and Lund 2009).

Romania is one such country which has experienced the full impact of these drastic reforms (Swinnen, 1997; Szelenyi, 1998; Turnock, 1998; Sikor, 2003) which gave away the control over resources from the state and its collective units to private individuals (Swinnen et al., 1997; Tangermann and Banse, 2000; Leonormand, 2001).

Initially this change was enthusiastically received by Romanian peasants due to its wider political implications. However, postsocialist academics are of the opinion that the state enforced here alien notions of property and individual wealth that were a far cry from previous community-centred strategies (Fox, 2009; Humphrey, 1995; Kaneff, 1995; Hivon, 1998; Dorondel and Sikor, 2009; Hann, 2007).

To further compound the issue, along with this broad shift in resource governance came significant gaps between legislation and rights-in-practice (Sikor, Stahl and Dorondel, 2009; Sikor and Lund, 2009; Sikor, 2003). This discrepancy meant the exclusion of some interests in favour of the interests of those of more powerful individuals (Sikor, 2003), a situation which was widely reported in postsocialist and postcolonial case studies (Boone, 2003; Comaroff and Comaroff, 1999; Corbridge et al., 2005; Das and Poole, 2004; Hansen and Stepputat, 2005; Lund, 2007; Migdal, 2001; Verdery, 1996, 2002, 2003; MungiuPippidi, 2005; Fox, 2009; Sikor, Stahl and Dorondel, 2009).

It would therefore seem that Romania has been the witness of a diversity of changes in property and rural property relations, which have varied depending on which legal property rights overlapped with which rights-in-practice (de Waal, 1996; Giordano and Kostova, 1996; Verdery 1999; Sikor, 2003).

As a consequence of the aforesaid changes, postsocialist academics blamed local conflicts here on the postsocialist transformations themselves and on their inclination to remove people from their previously lived land experiences (Hollis, 1999; Verdery, 1996, 1999, 2002, 2003; Sikor, 2003; Dorondel and Sikor, 2009). What this review paper will be concerned with is the fact that the ensuing struggles over resources were also considered by academics to have played an important part in the formation of the postsocialist state (von Benda-Beckmann, 1981; Stark and Bruszt, 1998; Kurtz and Barnes, 2002; Verdery, 2002; Sikor, 2003; Sturgeon and Sikor, 2004; Sikor and Lund, 2009; Sikor, Stahl and Dorondel, 2009). 


\author{
(online) = ISSN $2285-3642$ \\ ISSN-L = $2285-3642$ \\ Journal of Economic Development, Environment and People \\ Volume 2, Issue 1, 2013 \\ URL: http://jedep.spiruharet.ro \\ e-mail: office jedep@spiruharet.ro
}

In order to better understand postsocialist transformations and their impact on state formation, this paper therefore suggests a critical review of current postsocialist literature focusing on postsocialism and postsocialist state formation.

By initially addressing the concepts used in the argument and only then moving on to its interpretation of postsocialist change and state formation, this paper hopes to provide a comprehensive picture of how the changing access to resources is able to influence the power and authority of the new postsocialist state. The paper will look at rural Romania through its own conceptual lens, with a particular emphasis on conflict to explain how the changing access to resources influences and is therefore linked to the power and authority of the new Romanian state.

It will thus firstly narrow its focus on the review of current postsocialist thinking on the concepts of property, access, power, state and authority. The way in which they have been explored by various scholars in postsocialist cases studies will also be briefly expanded upon so as to give the reader a better sense of what these concepts are and how useful they can be when trying to make sense of a postsocialist setting.

After these clarifications, the review paper will look more closely at its interpretation of postsocialist change. The second half of the paper will therefore link the concepts of property and access to resources with those of power and authority by placing an emphasis on conflicts. In accordance with current postsocialist thinking (Berry, 1993; Lund, 2002; Verdery, 2002; Ribot and Peluso, 2003; Sikor, 2006; Sikor and Lund, 2009; Sikor, Stahl and Dorondel, 2009), this paper thus hopes to corroborate its presupposition that access to resources influences postsocialist state power, authority and ultimately state formation itself.

Current postsocialist literature points to these struggles over natural resources as underlying processes of everyday state formation (Verdery, 1996; Verdery, 2002; Scott, 1998, 2005; Fox, 2009; Sikor, Stahl and Dorondel, 2009). Since post-socialist property relations are widely viewed as being underlined by political contestations at both a local and national level (Rabinowicz and Swinnen, 1997; Swinnen and Mathjs, 1997; Szelenyi, 1998; Verdery, 1999; Sturgeon and Sikor, 2004), this paper will really focus on the important role of conflicts in a postsocialist setting so as to further strengthen its theory.

The paper intends to analyse how these various conflicts link the changing access over resources to the power, authority and formation of the new Romanian state, by relating them to the current literature on postsocialist property and power relations. Conflicts over resources will be brought out as the central dynamic of the postsocialist state (Verdery, 1996; Verdery, 2002; Scott, 1998, 2005; Fox, 2009; Sikor, Stahl and Dorondel, 2009). Due to these struggles being seen as an essential part of the Romanian postsocialist state formation, the originality of this review paper also comes from its specific accent on conflict.

Aside from this interpretation and analysis of current postsocialist literature, the review paper will also suggest where future investigation might be rewarding. In according with current literature, it argues that it would be interesting to investigate in a field study the processes through which these 


\author{
(online) = ISSN $2285-3642$ \\ ISSN-L = $2285-3642$ \\ Journal of Economic Development, Environment and People \\ Volume 2, Issue 1, 2013 \\ URL: http://jedep.spiruharet.ro \\ e-mail: office jedep@spiruharet.ro
}

various actors obtain power and maintain control over resources (Fortmann, 1995; Rocheleau and Ross, 1995; Sikor, 2006; Sikor and Lund, 2009; Sikor, Stahl and Dorondel, 2009).

It proposes a spotlight on institutions as regularized patterns of behaviour between individuals and groups in society (Mearns, 1995; Leach et al., 1999). It posits that institutions play a crucial role in mediating environment-society relationships, and suggests the need for a future analysis of the ecological and social dynamics behind the concepts of property, access, power and authority (Leach and Mearns, 1991; Mearns, 1995; Mearns, 1996).

\title{
2. The main concepts reviewed: property, access to resources, power, authority and the state
}

The last few decades have been witness to a significant focus on property as a means of making sense of the transformations undergone by postsocialist and postcolonial states (Demsetz, 1967; Firmin and Sellers, 1996, 2000; Platteau, 1996; Verdery, 1999; Sikor, 2004; Dorondel and Sikor, 2009). This was the result of changes and upheavals in both postsocialist and postcolonial countries throughout the world. Asia, Africa, Latin America and Europe have all seen some radical shifts in the last two decades regarding control over land, away from collective agricultural units to individual property holders (Sikor and Müller, 2009).

At its most basic level, property is understood as representing the relationships between social actors with regards to objects of value (von Benda-Beckmann et al., 2006; Sikor and Lund, 2009). The state plays a crucial role here in facilitating these relationships and in linking various actors together, as well as enforcing any subsequent claims on land and natural resources (MacPherson, 1978: 3).

So, while varied (Akram-Lodhi, Borras and Kay, 2007; Bernstein, 2002; Byres, 2004; Otsuka and Place, 2001) in their approach to understand post-totalitarian reforms, all of these past studies have had a central theme: a focus on property and the state as a means of comprehending the changes sweeping these nations.

Studies in the last two decades comprise many such examples. One instance is the study of redistributive land reforms in Brazil (Ludgewigs et al., 2009; Pacheco, 2009). Studies there looked at the allocation mechanisms being employed in the country, meant to be "market-friendly" or "marketassisted" (Borras, 2003; Boucher, Barham and Carter, 2005): that is the redistribution of property through markets, facilitated by the state. Other studies focusing on Sub-Saharan Africa tackled property legislation and land tilting (Bruce and Migot-Adholla, 1994; Peters, 2009; Place, 2009), where countries whose governments had established specialised procedures for land registration were put under the microscope and criticised for their inability to take into account the potential of collective tenure systems. Postsocialist studies engaged with similar analyses (Fay, 2009; Upton, 2009) also trained their eye on the redistribution of agricultural land by the state to its historical owners (Swinnen, 1997; Verdery, 2003; Wegren, 1998) and the problems associated with it. 


\author{
(online) = ISSN $2285-3642$ \\ ISSN-L = $2285-3642$ \\ Journal of Economic Development, Environment and People \\ Volume 2, Issue 1, 2013 \\ URL: http://jedep.spiruharet.ro \\ e-mail: office jedep@spiruharet.ro
}

It is for that reason safe to say that a significant proportion of postsocialist and postcolonial studies all over the world have focused significantly on property and the role of the state as primary initiator and enforcer of property rights.

However, these relations in regards to property only exist at the formal level of laws, regulations, norms and practices which are legitimized and sanctioned by the resident politico-legal authority i.e. the state (Sikor and Lund, 2009). And, like in postcolonial contexts, property relations in a postsocialist context are in reality not very clear cut. They have been found to be fluid and negotiable as a result of the multitude of institutions competing here over authority (von Benda-Beckmann and von BendaBeckmann, 1999; Berry, 1993, 2002; Juul and Lund, 2002; Moore, 1998; Shipton and Goheen, 1992; Sturgeon and Sikor, 2004; Verdery, 1999). This signifies that the former ways of understanding postsocialist transformations through property are relevant but incomplete, due to their inability to take into account practices and property relations outside of the sanctioned legal system.

This is where the concept of access to resources comes in. Property is now being increasingly seen by many scholars as being one part of a larger picture: that of access to resources (Fortmann, 1985; Peluso, 1992; Bruce et al., 1993; Vandergeest and Peluso, 1995; Rocheleau and Edmunds, 1997; Sikor, 2006; Sikor and Lund, 2009). Access to resources is thus addressed due to the reality that despite them actually representing an important element in people's livelihoods, not all forms of access to resources and their benefits are legally guaranteed by the state.

So what does access represent then as a concept of postsocialist analysis? Access encompasses property and is at the same time much broader than it, for it covers all forms of possession which the law or other social norms often do not (Leach et al., 1999; Ribot and Peluso, 2003; Sikor and Lund, 2009). While postsocialist property is still widely discussed in the literature, it is now often clearly set apart from access to resources, which is the more encompassing and comprehensive way of analysing postsocialist transformations.

Like in the case of the postcolonial states (Boone, 2003; Comaroff and Comaroff, 1999; Corbridge et al., 2005; Das and Poole, 2004; Hansen and Stepputat, 2005; Lund, 2007; Migdal, 2001), postsocialist land owners realised that they were in actuality unable to successfully translate their formal ownership into "effective ownership" (Ribot, 1998; Verdery, 2003). This discrepancy is currently being explored by academics through the analysis of access to natural resources in a postsocialist setting.

The focus on access is thus due to property being regarded nowadays as too narrow an analytical lens (Sikor and Lund, 2009). This is a result of academics discovering other mechanisms throughout the years which open, influence, hinder or close access to resources instead (Fortmann, 1985; Peluso, 1992; Bruce et al., 1993; Vandergeest and Peluso, 1995; Rocheleau and Edmunds, 1997; Ribot and Peluso, 2003; Sikor, 2006). The past few decades have abounded in case studies of access as a primary way for social actors to benefit from resources.

So, it is rather through access that actors gain and maintain benefits from the resources to which they might otherwise not be legally entitled (Leach et al., 1999; Ribot and Peluso, 2003). This situation is 


\author{
(online) = ISSN $2285-3642$ \\ ISSN-L = $2285-3642$ \\ Journal of Economic Development, Environment and People \\ Volume 2, Issue 1, 2013 \\ URL: http://jedep.spiruharet.ro \\ e-mail: office jedep@spiruharet.ro
}

illustrated in many postsocialist or postcolonial cases. One such example is found in Ribot's (1998) analysis of the distribution of benefits along the charcoal commodity chain in Senegal. From processing, transport and trade, charcoal passes on benefits to more than just the villagers owning the property from which it is extracted. In this way very many actors, such as migrant woodcutters, merchants, transporters and salesman can benefit from charcoal through their ability to gain and maintain control over the access mechanisms related to the charcoal chain- access to markets, to transport, to labour etc. Similarly it has been found in other former totalitarian cases, such as Peluso's (1996) analysis of Indonesia, that kinship and other social relations often prevail over formal property rights and these are the mechanisms which in reality redistribute benefits from the Durian fruit trees.

Examples of this nature are also found in the postsocialist states of Central and Eastern Europe. Millions of property owners here found that, despite having legal rights to land, enforcing such rights is not an easy feat- even with the state backing them up. Villagers in Romania for example were found as not being able to translate their legal ownership into an "effective ownership" (Verdery, 2003) due to more powerful actors controlling the access to forest resources (Giordano and Kostova, 2002). So, like in Ribot's (1998) article on Senegal's charcoal trade, lack of technology, knowledge, credit and access to markets (i.e. market mechanisms) meant here that the legal owners were unable to extract the full extent of benefits which they were expecting (Hann, 1993; Verdery, 2003; Sikor, Stahl and Dorondel, 2009).

While the concepts of access to resources and property have been described to be important in postsocialist literature, one can see that there is another concept which surfaces in the reading: that of the state.

But why is the state important in this context and what does it represent here? In all postsocialist and postcolonial projects, one finds that the state plays a key role in initially distributing property rights and later in enforcing them (MacPherson, 2002; Lund, 2006). Therefore it not only performs but also enforces territoriality and, while actors may rebel against it, it is regarded by many as the ultimate authority in land disputes (Vandergeest and Peluso, 1998; Fogel, King and Shanker, 2008).

Aside from being the main politico-legal institution controlling the distribution of land, the state can be seen as many things. It can be the idea of the state (Abrams, 1988) but it can also represent the more concrete, on-the-ground practices of its state actors. Some authors like Fox (2009) may even replace the concept of "state" with that of power when approaching recent land transformations in postsocialist settings. Depending on the author, the state can represent many things in post-totalitarian studies.

What is interesting here about the concept of state and its actions of territoriality is that on the ground one actually notices that the reifications promoted by this institution melt away. Fox (2009) for example noticed that while the Romanian government attempted to match reality with their technological grids, people in reality end up building their own practices, acts of compliance, resistance as well as delineations of property (Scott, 1998; 2005). This is also observed in postcolonial states such as 


\author{
(online) = ISSN $2285-3642$ \\ ISSN-L = $2285-3642$ \\ Journal of Economic Development, Environment and People \\ Volume 2, Issue 1, 2013 \\ URL: http://jedep.spiruharet.ro \\ e-mail: office jedep@spiruharet.ro
}

Thailand, where Vandergeest and Peluso (1998) note that these resistances occur as a result of the state not taking into account important social dynamics (Fogel, King and Shanker, 2008).

Some authors have found it very compelling therefore to explore the "grey zones" that appear in these countries, between what the state legislates and who actually has the power to give access to resources. Authors such as Sikor (2004) and Sikor and Lund (2009) suggest the need for further investigation in this area, into the way in which the competition for society's vital resources is structured and into the way in which polities emerge, recede and consolidate themselves here through varying practices of legitimization, inclusion, exclusion and violence.

It would seem that other forces beside the state and formal property rights are at work in postsocialist countries (Sikor and Lund, 2009). It is these access mechanisms that have been touted as playing a crucial role in the variations noted between property rights and rights-in-practice.

Although, importantly, it must be noted that property, access to resources and the state are only half of the story. To further understand the picture of postsocialism, one must turn their attention to the other half of the story: to the concepts of power and authority in the new state.

As Sikor (2004) describes, the new land reforms in postsocialist countries challenged previous historical distributions of power. Postsocialist land legislation enforced a strict hierarchy of control over land and resources, in stark contrast with the previously flexible lived land relations (Sikor, 2004).

The actors involved ended up having to incorporate elements of this new legislation but also attempting to preserve certain features of the historical land relations. As a consequence, conflicts between the new and the old appeared here as the various actors attempted to legitimize their claims over resources and to consolidate their power (Sikor and Lund, 2009) - with more powerful actors even trying to launder their power as authority.

This is why it has been emphasised in current postcolonial and postsocialist studies that the government's state-centric approach to property does not take place in a political vacuum (Verdery, 1996, 2002, 2003; Mungiu-Pippidi, 2005; Fox, 2009; Sikor, Stahl and Dorondel, 2009; Sikor and Lund, 2009). As Dorondel and Sikor (2009) aptly put it, people are not merely passive victims to postsocialism. So, while governments promote private property, villagers and local officials fight back in order to assert their various property claims. The new property relations are for that reason often based on more than formal rights, they are also crucially based on power, notions of kinship, identity, family heritage, social well-being and respect (Leach et al., 1999; Ribot and Peluso, 2003; Dorondel and Sikor, 2009).

This struggle for power is also seen in rural Romania. Rural people here have had to constantly fight over access to resources (Verdery, 1996), as a result of the upheavals in power and lived land relations brought on by the change in political regimes. Various actors have tried to gain and maintain power over resources and their benefits. Local authorities in particular have taken advantage of their newly found powers and have hijacked legal processes so as to have access and control over resources (Kaneff, 1996; Verdery, 1996, 2002; Mungiu-Pippidi, 2005; Sikor, Stahl and Dorondel, 2009). Many have specifically abused the decentralization process to do exactly what Sikor and Lund (2009) have described: to launder their new powers as the ultimate authority on the matter. This situation is very similar to the changes 


\author{
(online) = ISSN $2285-3642$ \\ ISSN-L = $2285-3642$ \\ Journal of Economic Development, Environment and People \\ Volume 2, Issue 1, 2013 \\ URL: http://jedep.spiruharet.ro \\ e-mail: office jedep@spiruharet.ro
}

experienced in many other post-totalitarian cases such as the land tilting process in rural Nicaragua or in Thailand. Authors such as Broegaard (2009) and Vandergeest and Peluso (1995) describe how less powerful actors often cannot obtain land titles or gain access to resource benefits and thus miss out to those who are more powerful.

As a result, conflicts are commonplace in many postsocialist and postcolonial states. They are usually underlined by the competition between a personalized and a law-governed exercise of state authority (Hollis, 1999; Verdery, 1996, 1999, 2002, 2003; Sikor, Stahl and Dorondel, 2009).

It can be safely concluded that, while initiated by the state, the process of land privatization is not merely the by-product of central government (Sikor, Stahl and Dorondel, 2009). Because the state neglects important local-historical and social dimensions of property rights (Dorondel and Sikor, 2009), the rural actors involved often have to compete with each other for the power to secure access to forest resources or to ensure the enforcement of property legislation (Sikor, 2003).

The meeting point between these actors of various powers is where the concept of authority finally comes into play. It is frequently employed in post-totalitarian literature to denote the influence of the state in the management of natural resources and the way in which certain actors are able to gain or regain control over resources (von Benda-Beckmann, 1981; Stark and Bruszt, 1998; Kurtz and Barnes, 2002; Verdery, 2002; Sturgeon and Sikor, 2004; Sikor and Lund, 2009) .

Case studies in Romania (Verdery, 1996, 2002, 2003; Mungiu-Pippidi, 2005; Fox, 2009; Sikor, Stahl and Dorondel, 2009) are full of stories about disappointed rural owners who turn to corrupt means of gaining access to resources. In most of these studies, it was local officials who were principally responsible for unravelling property as the key means to distributing property resource benefits, by gaining control over access mechanisms and laundering power for authority (Sikor, Stahl and Dorondel, 2009).

So where exactly does authority come in? After restitution, many people in Romania felt that they had been disadvantaged by the state and therefore sought the reconfiguration of property and access through extra-legal means (Sikor, 2003; Mungiu-Pippidi, 2005; Verdery, 2002, 2003; Sikor, Stahl and Dorondel, 2009). Regardless of where access or power originated from, people appeared to have an inherent need to legitimize it (Sikor and Lund, 2009). Like in many postcolonial states, a lack of technology, knowledge, credit and access to markets (i.e. market mechanisms) may initially hold legal owners back (Hann, 1993; Ribot, 1998; Verdery, 2003; Sikor, Stahl and Dorondel, 2009). However, these disadvantages can soon be overcome by appealing to the greater authority of the state and of the law.

Examples also abound in current post-totalitarian literature of property owners resorting to the law, the state's authority or another relevant institution's authority so as to cement or make claims to land and resources. This situation is particularly prevalent in post-totalitarian settings where many institutions shop around for authority. Such cases have been noted in postcolonial states like Ghana (Lund, 2008) where people sought to authorize their claims either with the help of the state or the priests, or in 


\author{
(online) = ISSN $2285-3642$ \\ ISSN-L = $2285-3642$ \\ Journal of Economic Development, Environment and People \\ Volume 2, Issue 1, 2013 \\ URL: http://jedep.spiruharet.ro \\ e-mail: office jedep@spiruharet.ro
}

instances in Latin America where law and authority represent a major factor in maintaining Peruvian agricultural communities (Sikor and Müller, 2009).

As rural relations respond more to market pressure or other non-state influences (Sikor, 2003), conflicts deepen. While regrettable for the property owners who cannot extract the expected benefits (Verdery, 2003; Giordano and Kostova, 2002) this is a golden opportunity for the concept of state authority to manifest itself. Wronged property owners can and often do appeal to the state's authority to legitimise or re-assert their claims.

The state and its authority are as a result being currently explored in postsocialist literature. The state particularly is being pursued beyond its first role as distributor of property rights and initiator of land reforms (Sikor and Müller, 2009).

The first part of this paper has now described how postsocialist land reforms challenge previous distributions of property and power and influence the characteristics of the main concepts this review paper works with.

New land legislation in these countries is seen by postsocialist scholars to have enforced a strict hierarchy of control over land and resources, in stark contrast with previously flexible lived land relations (Sikor, 2004). The actors involved have therefore been forced to resort to the incorporation of elements from this new legislation, but also to attempt to preserve certain features of historical land relations.

The changes that occur as a result of postsocialism are seen to inevitably lead to conflict, as the actors involved all try to legitimize their own claims over resources and to consolidate their power (Sikor and Lund, 2009). The new postsocialist state comes into this situation too, assuming the primary role in property reforms (Stark and Bruszt, 1998): it tries to control property titles and constantly tries to reaffirm its position as the higher power (Kurtz and Barnes, 2002; Verdery, 2002).

Postsocialist literature has thus more recently been inclined to argue that in this context, all of these conflicts and negotiations are necessarily interwoven with and therefore lead to the construction of the postsocialist state (Verdery, 1996, 2002; Scott, 1998, 2005; Sturgeon and Sikor, 2004; Sikor, Stahl and Dorondel, 2009; Fox, 2009). Having explored the concepts needed to elucidate and understand how this process works the second part of this review paper will now be concerned with investigating how the changing access to resources and the ensuing conflicts lead to postsocialist state formation. This will be achieved by linking the concepts of property and access to resources to the concepts of power and authority. The paper will explore how these four concepts are connected via a thread of conflicts, and how this constantly reconnecting thread ultimately leads to the formation and consolidation of the new postsocialist state of Romania. 


\author{
(online) = ISSN $2285-3642$ \\ ISSN-L $=2285-3642$ \\ Journal of Economic Development, Environment and People \\ Volume 2, Issue 1, 2013 \\ URL: http://jedep.spiruharet.ro \\ e-mail: office jedep@spiruharet.ro
}

\title{
3. Exploring postsocialist Romania: linking the concepts of property and access to resources with those of power and authority \& showing how they lead to postsocialist state formation
}

While Romania's amorphous socio-political and institutional landscape may appear hard to grasp initially (Douglas, 1986; Cleaver, 2002) it can be made sense of, like Nujiten (2003) suggested, by looking at the attempts to control resources and at the forces at play amidst them (Sikor and Lund, 2009).

This review paper argues that these forces are reflected in and represented by the various conflicts over access between central state actors, local state authorities, historical landowners, new entrepreneurs and agricultural managers (Rabinowicz and Swinnen, 1997; Swinnen and Mathjs, 1997; Szelenyi, 1998; Verdery, 1999). All of these actors are seen to be fighting for legal rights to natural resources or access to them, and to ensure the translation of their rights into practice.

The demise of socialism in Romania, like in all of the other Central and Eastern European states, has been characterised by the waning and decentralization of state power (Sikor, 2003). In the past two decades, the country has therefore experienced a radical shift in resource governance, away from that of the previously dominant legal and administrative hierarchy of socialism towards that of markets (Swinnen, 1997; Swinnen et al. 1997; Sikor, 2003; Sikor and Lund 2009).

The restitution of property in Romania was initially undertaken by the state (Cartwright, 2001) and it has been argued that due to this important local and lived land relations were ignored (Sikor, 2003). In order to ensure the support of the majority of the rural population, the Romanian government also restricted the maximum areas of agricultural land that any one individual could receive, further spurring conflicts between local actors. The Romanian process of restitution can for these reasons be characterised as fraught with difficulty, and resulting in frequent displays of personalized instead of lawgoverned forms of exercising state authority (Hollis, 1999; Verdery, 1996, 1999, 2002, 2003; Sikor, Stahl and Dorondel, 2009).

In addition to these problems, it has been increasingly observed by academics that certain "grey zones" (Sikor and Lund, 2009) occur here between property legislation and rights-in-practice (Sikor, 2003). Although the Romanian state, as a politico-legal institution, officially guarantees access to forest resources and their benefits, these "grey zones" signify a discrepancy between who has authority to give access to resources and who actually has power to give access to resources (Sikor and Lund, 2009) i.e. who really makes the local decisions that will affect people's access to forest resources and benefits.

This paper wishes to shed light on this process of decision-making, by linking the crucial concepts explored in the first part of the paper and by placing particular emphasis on the crucial role of conflicts in this process. Aside from this, the review paper's second half intends to show how this entire process contributes to the Romanian state's postsocialist state formation.

In order to understand how postsocialist changes to resource access are linked to concepts of power and authority, one must first understand the history of Romania. Only then, using the concepts detailed 


\author{
(online) = ISSN $2285-3642$ \\ ISSN-L = $2285-3642$ \\ Journal of Economic Development, Environment and People \\ Volume 2, Issue 1, 2013 \\ URL: http://jedep.spiruharet.ro \\ e-mail: office jedep@spiruharet.ro
}

in the first part of the paper and showing how they are linked via a thread of conflicts, can the picture of postsocialist Romania finally come together. Firstly it will establish why these conflicts over resources arose in postsocialist Romania and how they have unfolded here. Only then will it turn to explain how said conflicts feed into postsocialist state formation.

So, what happened in Romania after the revolution? After Romania's democratic revolution of 1989, former high-ranking communist politicians took over (Hollis, 1999). While this in itself did generate a certain degree of dissatisfaction with the regime (Pop-Eleches, 2001; Tismaneanu and Kligman, 2001) it did not weaken the authority of the newly formed state in the eyes of the people (ibid.).

And, just like in other postsocialist and postcolonial states, property restitution began immediately. While these reforms were in principle meant to link economic and political benefits with private property (Deininger, 2003; de Soto, 2000; Schwartz, 2006; Hanna et al., 1995; Schwegler, 2008), they were in actuality considered to be the government's principal way of cementing its authority and legitimacy (Verdery, 1996; Stark and Bruszt, 1998).

Romania rapidly underwent radical privatization reforms (Swinnen, 1997; Szelenyi, 1998; Turnock, 1998; Sikor, 2003) which gave control over resources away from the state and its collective units to private individuals (Swinnen et al., 1997; Tagermann and Banse, 2000; Leonormand, 2001). While this restitution of private property took place partly as a response to postsocialist citizen expectations, it was revealed by scholars to be mostly due to the state's own desire to cement its power and authority and due to various international pressures which regarded private property as the basis for a thriving market economy (Deininger, 2003; de Soto, 2000; Schwartz, 2006; Hanna et al., 1996; Schwegler, 2008).

Therefore, local conflicts over resources rapidly erupted due primarily to the fact that the rural property owners' trajectory was being determined by actors located many kilometres away from their villages that were removed from their lived land experiences and their historical property relations (Sikor, 2003). Even the language regarding property introduced by the new government was alien and not typically found in the discourse of rural people (Hann, 2007).

An intrinsic conflict was thus created in the first instance between the Romanian peasants and the state, frequently seen in their opposition of the notion of land as a source of individual wealth (Fox, 2009). This was due to the fact that many rural actors still preferred to regard property as a communal resource (Humphrey, 1995; Kaneff, 1995; Hivon, 1998), often being tied to it by family bonds and historical identity rather than abstract economic strategy (Dorondel and Sikor, 2009).

Aside from the original conflicts of values and trajectory between the state and its rural property owners, another important source of conflict has been the redistribution of property rights among actors at the local level. These local actors are in competition over resources and this paper argues that it is their struggles that play a crucial role in connecting the concepts of property, access to resources, power and authority in postsocialist Romania.

After the revolution, property reforms in Romania became the essential component of the newly formed state's transformation (Verdery, 2004; Sikor, Stahl and Dorondel, 2009; Staddon, 2000, 2001). 


\author{
(online) $=$ ISSN $2285-3642$ \\ ISSN-L = $2285-3642$ \\ Journal of Economic Development, Environment and People \\ Volume 2, Issue 1, 2013 \\ URL: http://jedep.spiruharet.ro \\ e-mail: office jedep@spiruharet.ro
}

However, despite the hopes of individual economic prosperity these changes prompted, in reality they quickly gave rise to a monopolistic market structure, which reduced the returns of property for landowners and offered sizeable profits to more powerful local and national actors instead (Giordano and Kostova, 1996).

It soon became clear to the new property owners that along with newly found freedom and hope this broad shift in resource governance also brings significant gaps between legislation and rights-inpractice (Sikor, Stahl and Dorondel, 2009), depending on who holds the most power. This meant that when the state changed and became more decentralized, it inadvertently caused significant gaps or "grey zones" (Sikor and Lund, 2009) between property legislation and rights-in-practice (Sikor, 2003), a discrepancy which lead to the exclusion of some interests in favour of the interests of more powerful individuals (Sikor, 2003).

Like scholars have repeatedly observed in postcolonial states (Boone, 2003; Comaroff and Comaroff, 1999; Corbridge et al., 2005; Das and Poole, 2004; Hansen and Stepputat, 2005; Lund, 2007; Migdal, 2001), postsocialist land owners here were unable to successfully translate their formal ownership into "effective ownership" (Ribot, 1998; Verdery, 2003) due to the practices of more powerful actors.

So, during this time, Romania saw the advent of diverse rural property relations, which varied depending on which legal property rights overlapped with which rights-in-practice (de Waal, 1996; Giordano and Kostova, 1996; Verdery 1999; Sikor, 2003). Therefore post-socialist property relations were described here as being frequently ambiguous (Verdery, 1999; Sturgeon and Sikor, 2004), and underlined by political contestations at both a local and national level (Rabinowicz and Swinnen, 1997; Swinnen and Mathjs, 1997; Szelenyi, 1998; Verdery, 1999).

Frequent conflicts over resources erupted throughout the years in rural Romania. Increasingly, as rural relations responded more to market pressures or other non-state influences (Sikor, 2003), these conflicts deepened. Regrettably for property owners, this meant that those local actors with sufficient power were able to control access to resources and their benefits. Like in other post-socialist countries, rural Romania saw the rapid emergence of rural elites (Verdery, 1999, 2003; Lampland, 2002; MungiuPippidi and Althabe, 2002; Patterson, 2009) who tried to enforce new boundaries. Local newspapers abounded in stories of corruption (Verdery, 1996, 2002): local officials, abusing powers and authority given to them by the Local Government Autonomy of 1991 (Verdery, 1996), formed mafia-like networks and padded their pockets with benefits by controlling the access to property resources (Mungiu-Pippidi, 2005; Verdery, 2002, 2003; Sikor, Stahl and Dorondel, 2009).

It would appear that different forces other than the state (Sikor and Lund, 2009) have lead to great variations between property rights and rights-in-practice in Romania. As Sikor (2004) describes it, these new land reforms challenged previous distributions of power, superimposing a starkly different, unified hierarchy and redistribution on pre-existing social distributions and controls over land. This explains why local authorities and people countered this influence through frequent extra-legal means. 


\author{
(online) = ISSN $2285-3642$ \\ ISSN-L = $2285-3642$ \\ Journal of Economic Development, Environment and People \\ Volume 2, Issue 1, 2013 \\ URL: http://jedep.spiruharet.ro \\ e-mail: office jedep@spiruharet.ro
}

Conflicts over resources such as these found in Romania are thus rightly considered by many postsocialist authors as representing a central dynamic in the postsocialist state (de Waal, 1996; Giordano and Kostova, 1996; Verdery, 1999; Rabinowicz and Swinnen, 1997; Swinnen and Mathjs, 1997; Szelenyi, 1998; Sikor, 2003; Sikor, Stahl and Dorondel, 2009; Dorondel and Sikor, 2009). Current literature on postsocialist property points to these struggles over natural resources more specifically as "processes of everyday state formation" (Lund, 2002; Sikor and Lund, 2009; Verdery, 2002; Scott, 1998, 2005; Fox, 2009).

This is explained as being due to the fact that these legitimizing practices and conflicts appear to underpin all access and control over property and natural resources, as has been pointed out in Romania's example above.

This paper has highlighted the important role of conflicts in this process of state formation and suggests the need for a further investigation, as well as one into the actors' legitimizing practices (Foucault, 1980; Fortmann, 1995; Rocheleau and Ross, 1995; Ferguson and Gupta, 2002; Li, 2007), in order to shed light on Romania's current resource management and postsocialist state formation.

The rest of this review paper will now be concerned with how these various conflicts link the changing access over resources to power, authority and the formation of the new Romanian state. This will be explored by relating these concepts to the larger literature on postsocialist property and power relations.

Having previously ascertained that Romanian legal property owners were left in an unfavourable position after socialism, it is time to investigate how they reacted to these conflicts and show how their struggles to regain property rights feed into the power and authority of the newly formed state.

This paper has previously described how postsocialist land reforms challenge previous distributions of property and power. Postsocialist land legislation enforces a strict hierarchy of control over land and resources, in stark contrast with previously flexible lived land relations (Sikor, 2004). The actors involved are forced to incorporate elements of this new legislation while also attempting to preserve certain features of historical land relations. The transformations that occur lead to conflict, as the actors involved have the inherent need to legitimize their claims over resources and to consolidate their power (Sikor and Lund, 2009).

Postsocialist academics have duly noted that guaranteeing property rights for some people in these post-totalitarian contexts inevitably means denying the very same rights to others (Verdery, 1996, 2002, 2003; Mungiu-Pippidi, 2005; Fox, 2009; Sikor, Stahl and Dorondel, 2009). Such decisions however do not take place in a political vacuum and are often met with resistance.

So, in order to fully understand Romania's postsocialist transformations, this paper stresses the importance of addressing not only property and the access and control of forest resources, but also forms of resistance and conflicts, and how these relate to the forming power and authority of the postsocialist state (Fortmann, 1985; Peluso, 1992; Bruce et al., 1993; Vandergeest and Peluso, 1995; Rocheleau and Edmunds, 1997; Sikor, 2006). 


\author{
(online) = ISSN $2285-3642$ \\ ISSN-L = $2285-3642$ \\ Journal of Economic Development, Environment and People \\ Volume 2, Issue 1, 2013 \\ URL: http://jedep.spiruharet.ro \\ e-mail: office jedep@spiruharet.ro
}

Postsocialist thinking currently posits these struggles over access and control to be embedded in broader power and authority relations (Berry, 1993; Lund, 2002; Verdery, 2002; Ribot and Peluso, 2003; Sikor, 2006; Sikor and Lund, 2009; Sikor, Stahl and Dorondel, 2009), as they not only influence resource management, but actively contribute to the formation of the postsocialist Romanian state (Sikor and Lund, 2009; Sikor, Stahl and Dorondel, 2009).

This is also what this review paper argues, by tracing the thinking of current postsocialist literature. It maintains that access and control over resources and the power, authority and creation of the new state are tightly interwoven, as a result of the everyday struggles over natural resources.

The paper encourages the use of access analysis (Peluso, 1996; Ribot, 1998; Sikor and Lund, 2009; Sikor, Stahl and Dorondel, 2009), which is capable of uncovering the forces and dynamics behind resource management (Ribot, 1998), and the ways in which this is achieved (Peluso, 1996; Sikor and Lund, 2009; Sikor, Stahl and Dorondel, 2009). To give depth to the analysis, it also suggests looking at the powers and authority behind this transformation of property, and subsequently, of the very country itself (Berry, 1993; Lund, 2002; Verdery, 2002; Ribot and Peluso, 2003; Sikor, 2006; Sikor and Lund 2009; Sikor, Stahl and Dorondel, 2009). This type of combined access-power analysis not only focuses on the importance of changing access to resources for postsocialist state formation, but also is capable of reinforcing how crucial conflicts are in a postsocialist setting.

Individual property rights in Romania thus signalled a break with socialism, the birth of new political rights, participation in the economy and renewed hopes (Sikor, Stahl and Dorondel, 2009). Property especially represented the first and foremost field politico-legal institutions competed for. Like in other postsocialist and postcolonial settings, these institutions tried to establish their authority (Berry, 2002; Lund, 2002, 2006; Verdery, 1996).

Since the initial restitution of land gave away authority to competing local institutions, this meant that the authority of the state was at stake during these transformations. But the state quickly wised up that shopping for property claims reinforces its position (Verdery, 1996; Sikor, Stahl and Dorondel, 2009). In an environment rife with local corruption (Kaneff, 1996; Verdery, 1996, 2002; Mungiu-Pippidi, 2005; Sikor, Stahl and Dorondel, 2009) this meant that the state was in a strong position to establish, consolidate and expand its authority (Verdery, 1999, 2002) and shop for authority and legitimacy.

Due to the reasons highlighted in the first part of this argument, rural property owners here, like in other postsocialist countries (Rabinowicz and Swinnen, 1997; Swinnen and Mathjs, 1997; Szelenyi, 1998; Verdery, 1999; Sikor, 2004; Verdery, 1996, 2002, 2003; Mungiu-Pippidi, 2005; Fox, 2009; Sikor, Stahl and Dorondel, 2009; Sikor and Lund, 2009), began resisting the implementation of the new land legislation and conflicts over resources became widespread. Where authority relations overlapped, the rural people had to direct their claims to the main politico-legal institution: the state (Sikor and Lund, 2009).

Property rights, just like citizen rights, are produced, endorsed and sanctioned by the legitimate authority of the state. Property is therefore connected to authority (Weber, 1976) and depends on it for support (von Benda-Beckmann, 1995). So, when authority relations overlap, social actors are forced to 


\author{
(online) = ISSN $2285-3642$ \\ ISSN-L = $2285-3642$ \\ Journal of Economic Development, Environment and People \\ Volume 2, Issue 1, 2013 \\ URL: http://jedep.spiruharet.ro \\ e-mail: office jedep@spiruharet.ro
}

turn to the main politico-legal institution to clarify any ambiguities regarding property and property relations (Sikor and Lund, 2009; Berry, 1993).

Thus, in the tumultuous aftermath of the revolution, claimants sought the help of the state to authorize their property claims. Their reaction was natural, as rights and access to property resources are formally recognized and upheld by the state, and in turn by doing so, the state also gains authority to do the same in the future (Sikor, Stahl and Dorondel, 2009).

Since the state was also seeking claims to authorize in order to consolidate its position, this meant that a dynamic and interdependent relationship formed (von Benda-Beckmann, 1981; Lund, 2002; Sikor, Stahl and Dorondel, 2009). This reciprocal relationship has been characterised by academics as a social contract linking property and authority- which represents state formation (Lund, 2002).

The claimants and the state therefore have a dynamic relationship (von Benda-Beckmann, 1981; Stark and Bruszt, 1998; Kurtz and Barnes, 2002; Verdery, 2002) which lends legitimacy to the new state and leads to the construction of the post-socialist state itself (Sturgeon and Sikor, 2004).

Recent postsocialist literature supports this idea that the exercise of authority is intimately linked to the legitimacy and formation of the new state (von Benda-Beckmann, 1981; Stark and Bruszt, 1998; Kurtz and Barnes, 2002; Verdery, 2002; Sturgeon and Sikor, 2004; Sikor and Lund, 2009). Institutions such as this tend to argue or justify their legitimacy in relation to the concrete exercise of authority because they need to actively establish their legitimacy (Sikor and Lund, 2009). The new state assumes the primary role in property reforms (Stark and Bruszt, 1998), it controls property titles and then reaffirms its position as the higher power by settling property conflicts (Kurtz and Barnes, 2002; Verdery, 2002).

This is why it has been argued that property and access claims inevitably become processes through which authority is formed, as the local actors appeal to the authority of the main politico-legal institution to back their claims and solve their conflicts (von Benda-Beckmann, 1981; Stark and Bruszt, 1998; Kurtz and Barnes, 2002; Verdery, 2002).

In this postsocialist process, the local actors and the state are constantly forming, challenging and unravelling property rights through their various conflicts described above. For this reason, recent postsocialist literature has further argued that in this context, all of these struggles and negotiations are interwoven with the construction of the postsocialist state (Sturgeon and Sikor, 2004; Verdery, 2002; Scott, 1998, 2005; Fox, 2009; Verdery, 1996; Sikor, Stahl and Dorondel, 2009).

In conclusion, despite the difficult situation after the restitution of property, the systematic unravelling of property rights somehow only served to strengthen the Romanian state's authority as the property owners turned to it for the translation of laws to practice (Verdery, 1996; Sikor, Stahl and Dorondel, 2009). The respective property owners blamed individual politicians (Sikor, Stahl and Dorondel, 2009), while the state was viewed apart from these actions (Abrams, 1988) and became stronger due to the notions of private property that it upheld and its ability to enforce these rights where local authorities had failed (Sikor, Stahl and Dorondel, 2009). 


\author{
(online) = ISSN $2285-3642$ \\ ISSN-L = $2285-3642$ \\ Journal of Economic Development, Environment and People \\ Volume 2, Issue 1, 2013 \\ URL: http://jedep.spiruharet.ro \\ e-mail: office jedep@spiruharet.ro
}

This paper thus suggests for further investigation the postsocialist process via a combined accesspower analysis, with a special emphasis placed on the role of conflicts and legitimizing practices in shaping postsocialist state formation and in affecting natural resource management.

\title{
4. Future research: where to now
}

As the previous sections of this paper have established, property relations often appear ambiguous in postsocialist or postcolonial settings due to uncertain power and authority relations (Sikor, 2004; Verdery, 1999).

The postsocialist literature consulted appears torn between two schools of thought: postsocialist relations can be seen as "fuzzy" and guided by seemingly unclear rules or they can be seen as rules that become clearer the further the postsocialist state evolves from its revolution.

Thus, authors such as Sikor (2004) and Verdery (1999), point to the existence of a certain "fuzziness" in postsocialist states, due to the apparent lack of routinized rules and crystallized practices characterising postsocialist property relations.

On the other hand, more evolutionary approaches argue that as land becomes more valuable and transformations here more defined, narrower definitions of property emerge and clearer rights ensue (Demsetz, 1967; Firmin Shellers, 1996, 2000; Platteau, 1996). Whatever the situation, it would seem rewarding for future research to attempt an analysis of the transformations occurring in postsocialist states such as Romania.

Recent work on the matter suggests looking at concepts and the way in which truths are established in the tumultuous context of postsocialist transformations (Ferguson and Gupta, 2002; Foucault, 1980; Li, 2007). This approach understands access to be more than an instrument of analysis. People and institutions are thought to actively employ and interpret concepts in their attempts to enact their different political projects and interests. So, academics such as Sikor and Lund (2009) argue that it would be interesting to analyse how these various concepts and ideas of different origin enter a local arena where they become "idiomatized" and how this is achieved.

Another approach could be to focus on institutions and the ways in which these affect the dynamics of natural resource management and consequently the consolidation of the postsocialist state. Usually discussed by authors specialising in postcolonial states (Leach, Mearns and Scoones, 1999; Leach and Mearns, 1991; Mearns, 1995; Mearns, 1996), it highlights the central role of institutions in mediating and shaping environment-society relationships.

In this approach, institutions are taken to mean the regularized patterns of behaviour between individuals and groups in society, rather than just community-level organisations. This interpretation can be used to analyse how differently positioned social actors of varying power and authority are able to 


\author{
(online) = ISSN $2285-3642$ \\ ISSN-L = $2285-3642$ \\ Journal of Economic Development, Environment and People \\ Volume 2, Issue 1, 2013 \\ URL: http://jedep.spiruharet.ro \\ e-mail: office jedep@spiruharet.ro
}

command natural resources instrumental in their well-being. This type of approach would be well suited to the disaggregated concepts analysed in the beginning of this paper.

Therefore, such a focus on institutions would be able to elucidate how the changing ecological and social dynamics of postsocialist Romania have influenced natural resource management and the activities of various actors involved, as well as how these have shaped the environment and the formation of the new democratic state (Leach and Mearns, 1991; Mearns, 1995; Mearns, 1996).

The postsocialist environment which researchers frequently describe depends on ecological and social dynamics. A disaggregate analysis of the concepts linking the community with its natural resources would be helpful to shed light on postsocialist transformations. The ways in which different social actors gain power and access to resources can be explored through such an analysis in order to make sense of postsocialist change (Leach, Mearns and Scoones, 1999).

Recent advances in political ecology suggest that post-totalitarian environments are inevitably characterised and defined by a high variability in time and space (Leach, Mearns and Scoones 1999). This is especially relevant in postsocialist case studies which, like former colonial states, have now been seeing significant changes which have affected the way in which they manage their natural resources. A disaggregate approach to postsocialist society would be relevant, as a society such as Romania is made up of many active individuals and groups, constantly engaging in conflicts over resources and contributing to state formation (Verdery, 2002; Scott, 1998, 2005; Fox, 2009).

The relationships between various institutions would be therefore interesting to investigate, so as to determine which social actors gain access and control to local resources, how they manage these resources and thus shape the landscape and the new state over time.

This paper also believes that an institutional approach would be valuable in understanding the changes undergone by postsocialist states such as Romania, because it looks not only at a snapshot in time, but at the dynamic mapping processes that underlie each static set, which are mediated through various forms of institutions operating at either macro or micro level at various points in time (Leach, Mearns and Scoones, 1999).

\title{
5. Conclusion
}

It would thus appear that since 1989 Romania has seen some very intense negotiations over property and access to natural resources. People's expectations initially ran high, believing in the hopes of economic efficiency, social equity and democracy (Sikor, Stahl and Dorondel, 2009). These dreams however were soon dispelled by conflicts of interest and power struggles (Verdery, 2004; Sikor, 2006; Sikor, Stahl and Dorondel, 2009), with rural areas quickly becoming the backdrop for frantic struggles over property resources.

This paper has argued that the dynamics of property and authority in this postsocialist state have not only been radical, but have actively reinforced each other. It is precisely the simultaneous occurrence of property and authority negotiations which has created conflicts and ambiguities in property and 


\author{
(online) = ISSN $2285-3642$ \\ ISSN-L = $2285-3642$ \\ Journal of Economic Development, Environment and People \\ Volume 2, Issue 1, 2013 \\ URL: http://jedep.spiruharet.ro \\ e-mail: office jedep@spiruharet.ro
}

power relations (Sturgeon and Sikor, 2004). These negotiations and transformations challenge the very notions of property rights and that of the state, the distribution of property rights amongst social actors as well as the power and position of said actors.

The various actors involved are constantly competing for resource access and control, for fear of losing out on benefits and of being driven out by the competition. Some either focus their energy on gaining property via claims or influencing recognition of their claims, while others such as local officials focused instead on gaining access to property benefits via illegal logging, the control of the timber industry, bribes for protection or taking advantage of their position to gain a share of property benefits (Kaneff, 1996; Verdery, 1996, 2002; Mungiu-Pippidi, 2005; Sikor, Stahl and Dorondel, 2009).

Postsocialist politics are therefore characterized by contestations, which play out in these struggles over access and control of resources (Sikor, Stahl and Dorondel, 2009). Postsocialist land relations are "fuzzy" and characterised by the aforementioned conflicts over the control and use of natural resources (Verdery, 1999; Sikor, 2004; Sikor, Stahl and Dorondel, 2009).

By using access-power relations (Berry, 1993; Ribot and Peluso, 2003) and narrower propertyauthority relations (Lund, 2002; 2007) current postsocialist literature (Berry, 1993; Lund, 2002; Verdery, 2002; Ribot and Peluso, 2003; Sikor, 2006; Sikor and Lund, 2009; Sikor, Stahl and Dorondel, 2009) upholds that these struggles are inevitably entwined with the exercises of power and authority and the formation of the postsocialist state (Sikor and Lund, 2009).

The local authorities' predatory practices and the struggles of rural property owners to authorize their property claims only seem to strengthen the new state's authority (Verdery, 1996; Sikor, Stahl and Dorondel, 2009), while their fights over access and property, contestations of authority, legitimizing practices, territoriality and any violence are processes of everyday state formation (Verdery, 2002; Scott, 1998, 2005; Fox, 2009).

The stage is hence set for a battle where the winners will be the social actors which are able to command the most advantageous economic, political and cultural resources.

Future postsocialist and postcolonial research appears to be headed in this direction, towards the analysis of resource conflicts and legitimizing practices under changing political regimes. This paper reviews some of the methods suggested for this purpose, such as concept analysis or institutional analysis (Ferguson and Gupta, 2002; Foucault, 1980; Li, 2007; Sikor and Lund 2009; Leach, Mearns and Scoones, 1999). Particular emphasis is placed on institutional analysis, due to its ability to connect the concepts of access to resources with those of power and authority, and thus of elucidation the conflicts and legitimizing practices that occur within this context.

This institutional approach focuses on the role of institutions in mediating people-environment relations by mapping the underlying processes of natural resource management and postsocialist or postcolonial state formation. Authors supporting this approach (Leach, Mearns and Scoones, 1999) emphasise that there is a multitude of institutions involved in natural resource management which 


\author{
(online) = ISSN $2285-3642$ \\ ISSN-L = $2285-3642$ \\ Journal of Economic Development, Environment and People \\ Volume 2, Issue 1, 2013 \\ URL: http://jedep.spiruharet.ro \\ e-mail: office jedep@spiruharet.ro
}

people rely on to support their claims to environmental goods or services. These could in the future be further investigated in order to elucidate the complex process of state formation.

The environment is seen here as dynamic. The need to understand and contextualise resource conflicts is therefore considered paramount in order to make sense of the struggles these actors encounter and in order to possibly improve future resource management (Bradbury, Fisher and Lane 1995).

\title{
6. References:
}

[1] Abrams, P. (1988) 'Notes on the Difficulty of Studying the State', Journal of Historical Sociology 1(1): 5889.

[2] Akram-Lodhi, A. H., Borras, S. M., Jr. \& Kay, C. (Eds.) (2007). Land, poverty and livelihoods in the era of globalization: Perspectives from developing and transition countries. London: Routledge.

[3] Berry, S. (1993) No Condition is Permanent: The Social Dynamics of Agrarian Change in Sub-Saharan Africa. Madison, WI: University of Wisconsin Press.

[4] Bernstein, H. (2002). Land reform: Taking a long(er) view. Journal of Agrarian Change, 2, 433-463.

[5] Boone, C. (2003) Political Topographies of the African State: Territorial Authority and Institutional Choice. New York: Cambridge University Press.

[6] Borras, S. M. Jr., (2003). Questioning market-led agrarian reform: Experiences from Brazil, Colombia and South Africa.Journal ofAgrarian Change, 3, 367-394.

[7] Bradbury, M., Fisher, S., Lane, C., (1995). Working with pastoralist NGOs and land conŻict in Tanzania.IIED London.

[8] Broegaard, R. B. (2009), Land Access and Titling in Nicaragua. Development and Change, 40: 149-169. doi: 10.1111/j.1467-7660.2009.01509.x

[9] Bruce, J., Fortmann, L., Nhira, C., 1993. Tenures in transition, tenures in conflict: examples from the Zimbabwe social forest. Rural Sociology 58, 626-642.

[10] Bruce, J. W., \& Migot-Adholla, S. E. (1994).Searching for land tenure security in Africa. Dubuque, IO: Kendall/Hunt Publishing Company.

[11] Boucher, S. R., Barham, B. L., \& Carter, M. R. (2005).The impact of "Market-Friendly" reforms on credit and land markets in Honduras and Nicaragua.World Development, 33, 107-128.

[12] Byres, T. J. (2004). Neo-classical neo-populism 25 years on: Deja vu and deja passe. Towards a critique.Journal of Agrarian Change, 4, 17-44.

[13] Cartwright, A.L. (2000) 'State Law and the Recognition of Property in Rural Romania'. MPI Working Paper No 10. Halle: Max Planck Institute for Social Anthropology.

[14] Cleaver, F. (2002) 'Reinventing Institutions: Bricolage and the Social Embeddedness of Natural Resource Management', European Journal of Development Research 14(2): 11-30.

[15] Comaroff, J.L. and J. Comaroff (eds) (1999) Civil Society and the Political Imagination in Africa. Chicago, IL: University of Chicago Press.

[16] Corbridge, S., M. Srivastava and R. Veron (2005) Seeing the State: Governance and Governmentality in India. Cambridge: Cambridge University Press. 


\author{
(online) = ISSN $2285-3642$ \\ ISSN-L = $2285-3642$ \\ Journal of Economic Development, Environment and People \\ Volume 2, Issue 1, 2013 \\ URL: http://jedep.spiruharet.ro \\ e-mail: office jedep@spiruharet.ro
}

[17] Das, V. and D. Poole (eds) (2004) Anthropology at the Margins of the State. Santa Fe, NM: School of American Research Press.

[18] De Soto H., (2000). The Mystery of Capital. Why Capitalism Triumphs in the West and Fails Everywhere Else. New York: Basic Books.

[19] de Waal, C. (1996). Decollectivisation and total scarcity in high Albania.Pages 169-192.inR. Abrahams Eds, After social-ism: land reform and social change in Eastern Europe. Berghahn Books, Oxford.

[20] Deininger, K., (2003). Land Policies for Growth and Poverty Reduction. World Bank and Oxford University Press, Washington, D.C.

[21] Demsetz, H. (1967) 'Toward a Theory of Property Rights', American Economic Review 57(2): 347-59.

[22] Dorondel, S., Sikor, T. (2009), Private Property: From Postsocialism to Neoliberalism?, Annuaire Roumain d'Anthropologie, Vol. 46, pp. 55-62,.

[23] Douglas, M. (1986) How Institutions Think. Syracuse, NY: Syracuse University Press.

[24] Derick Fay, Land Tenure, Land Use, and Land Reform at Dwesa-Cwebe, South Africa: Local Transformations and the Limits of the State, World Development, Volume 37, Issue 8, August 2009, Pages 1424-1433, ISSN 0305-750X, 10.1016/j.worlddev.2008.08.012.

(http://www.sciencedirect.com/science/article/pii/S0305750X09000576)

[25] Ferguson, J. and A. Gupta (2002) 'Spatializing States: Toward an Ethnography of Neoliberal Governmentality', American Ethnologist 29(4): 981-1002.

[26] Firmin-Sellers, K. (1996) The Transformation of Property Rights in the Gold Coast. Cambridge: Cambridge University Press.

[27] Firmin-Sellers, K. (2000) 'Custom, Capitalism, and the State: The Origins of Insecure Land Tenure in West Africa', Journal of Theoretical and Institutional Economics 156: 513-30.

[28] Fogel, A., King, B. J., \& Shanker, S. (Eds.), (2008). Human development in the 21st century: Visionary policy ideas from systems scientists. Cambridge, UK: Cambridge University Press. Published, 2008.

[29] Fortmann, L. (1995) Talking Claims: Discursive Strategies in Contesting Property. World Development 23(6), pp. 1053-1063.

[30] Fortmann, L., (1985). The tree tenure factor in agroforestry with particular reference to Africa. Agroforestry Systems 2, 229-251.

[31] Foucault, M. (1980) 'Truth and Power', in C. Gordon (ed.) Power/Knowledge, pp. 109-33. New York and London: Harvester Wheatsheaf.

[32] Fox, K. (2009). Confusion, secrecy and power: direct payments and European Integration in Romania. ANN.ROUM.ANTHROPOL.46, P.63-75.

[33] Giordano, C. And D. Kostova (2002), "The Social production of mistrust", in C. Hann (ed.), Post-socialism: Ideals, Ideologies and Practices in Eurasia, pp. 74-91. London: Routledge

[34] Giordano, C., and D. Kostova. (1996). Die Reprivatisierung ohne Bauern in der bulgarischen Landwirtschaft nach der ,Wende'. Zur Persistenz einer unheilvollen Tradition. Sudosteuropa Aktuell 25:49-63

[35] Gupta, A. and Ferguson, J., (2002), Spatialising States: Toward an Ethnography of Neoliberal Governmentality, American Ethnologist, 29, p. 981-1002. 


\author{
(online) = ISSN $2285-3642$ \\ ISSN-L = $2285-3642$ \\ Journal of Economic Development, Environment and People \\ Volume 2, Issue 1, 2013 \\ URL: http://jedep.spiruharet.ro \\ e-mail: office jedep@spiruharet.ro
}

[36] Hann M.C., (1993). From Production to Property: Decollectivization and the Family-Land Relationship in Contemporary Hungary. Man (N.S) 28: 299-320.

[37] Hann, C. (2007), Reconciling anthropologies. Anthropology Today, 23: 17-19. doi: 10.1111/j.14678322.2007.00549.x

[38] Hanna S., M. Munasinghe, (1995). Property Rights and the Environment. Washington D.C.: The World Bank.

[39] Hansen, T.B. and F. Stepputat (eds) (2005) Sovereign Bodies: Citizens, Migrants and States in the Postcolonial World. Princeton, NJ and Oxford: Princeton University Press.

[40] Hivon, M. (1998) The bullied farmer: Social pressure as a survival strategy? Pp. 33-51 in S. Bridger and F. Pine eds, Surviving Post-socialism: Local Strategies and Regional Responses inEastern Europe and the Former Soviet Union (London: Routledge).

[41] Hollis, W. (1999) Democratic Consolidation in Eastern Europe: The Influence of the Communist Legacy in Hungary, the Czech Republic, and Romania. Boulder, CO: Eastern European Monographs.

[42] Humphrey, C. (1995) 'The Politics of Privatization in Provincial Russia: Popular Opinions amid the Dilemmas of the Early 1990s', Cambridge Anthropology 18(1): 40-61.

[43] Juul, K. and C. Lund (eds) (2002) Negotiating Property in Africa. Portsmouth, NH: Heinemann.

[44] Kaneff D., (1996). Responses to "democratic" land reforms in a Bulgarian village, in Ray Abrahams (ed.), After Socialism: Land Reform and Social Change in Eastern Europe. Oxford: Berghahn Books, pp. 85-114.

[45] Kurtz, M.J. and A. Barnes (2002) 'The Political Foundations of Post-Communist Regimes', Comparative Political Studies 35(5): 524-53.

[46] Lampland M., (2002). The advantages of being collectivized.Cooperative farm managers in the postsocialist economy. In: C.M. Hann (ed.). Postsocialism. Ideals, ideologies and practices in Eurasia. 3156. London and New York: Routledge.

[47] Leach, M., Mearns, R. (1991). Poverty and environment in developing countries: An overview study. Report to ESRC, Global Environmental Change Programme; and Overseas Development Administration, ESRC, Swindon.

[48] Leach, M., R. Mearns, and I. Scoones (1999) Environmental Entitlements: Dynamics and Institutions in Community-Based Natural Resource Management. World Development 27(2), pp. 225-247.

[49] Lenormand, P. (2001). Political mutation and agricultural change in Eastern Europe.Pages 51-81.inH. Buller, and K. Hoggart. Eds, Agricultural transformation, food and environment: perspectives on European rural policy and planning, Volume 1. Ashgate, Aldershot, UK.

[50] Li, T.M. (2007) TheWill to Improve: Governmentality, Development, and the Practice of Politics. Durham, NC: Duke University Press.

[51] Ludewigs, T., Díantona, A., Brondìzio, E. S. and S. Hetrick (2009) "Agrarian Structure and Land-cover Change Along the Lifespan of Three Colonization Areas in the Brazilian Amazon," World Development, 37(8), 1348-1359.

[52] Lund, C. (2002) 'Negotiating Property Institutions: On the Symbiosis of Property and Authority in Africa', inK. Juul andC. Lund (eds) Negotiating Property in Africa, pp. 11-43. Portsmouth, NH: Heinemann. 


\author{
(online) = ISSN $2285-3642$ \\ ISSN-L = $2285-3642$ \\ Journal of Economic Development, Environment and People \\ Volume 2, Issue 1, 2013 \\ URL: http://jedep.spiruharet.ro \\ e-mail: office jedep@spiruharet.ro
}

[53] Lund, C. (2006) 'Twilight Institutions. Public Authority and Local Politics in Africa', Development and Change 37(4): 685-705.

[54] Lund, C. (ed.) (2007) Twilight Institutions: Public Authority and Local Politics in Africa. Oxford: Blackwell.

[55] Lund, C. (2008) Local Politics and the Dynamics of Property in Africa. Cambridge and New York: Cambridge University Press.

[56] MacPherson, C. B. (1978). Property: Mainstream and critical positions. Toronto: University of Toronto Press.

[57] MacPherson, C.B. (1978) 'Introduction', in C.B. MacPherson (ed.) Property: Mainstream and Critical Positions, pp. 1-13. Toronto: University of Toronto Press.

[58] Mearns, R., (1995). Institutions and natural resource management: Access to and control over woodfuel in East Africa. In Binns, T. (Ed.), People and Environment in Africa. John Wiley \& Sons, Chichester, pp. $103 \pm 114$.

[59] Mearns, R., (1995). Environmental entitlements: Towards empowerment for sustainable development. In ENVIRONMENTAL ENTITLEMENTS Singh N. and Titi V. (Eds.), Empowerment: Towards Sustainable

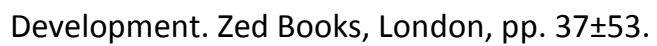

[60] Mearns, R., (1996). Environmental entitlements: pastoral natural resource management in Mongolia. Cahiers des Sciences Humaines 32 (1), 105 \pm 131.

[61] Mearns, R., (1996). Community, collective action and common grazing: the case of post-socialist Mongolia. Journal of Development Studies 32 (3), $297 \pm 339$.

[62] Mearns, R., (1996). Commons and collectives: The lack of social capital in Central Asia's land reforms.

[63] Migdal, J. (2001) State in Society: Studying How States and Societies Transform and Constitute One Another. Cambridge: Cambridge University Press.

[64] Moore, S.F. (1988) 'Legitimation as a Process: The Expansion of Government and Party in Tanzania', in R. Cohen and J.D. Toland (eds) State Formation and Political Legitimacy, pp. 155-72. New Brunswick, NJ: Transaction Books.

[65] Mungiu-Pippidi A., Althabe G., (2002). Secera şi buldozerul.Scornicesti şi Nucşoara.Mecanisme de aservire a ţăranului român [The Sickle and the Bulldozer.Scornicesti and Nucsoara.Mechanisms of Romanian Peasant Subjugation]. Iaşi: Polirom

[66] Mungiu-Pippidi, A. (2005) 'Reinventing the Peasants: Local State Capture in Post-Communist Europe', in S. Dorondel and S. Serban (eds) Between East and West: Studies in Anthropology and Social History, pp. 308-26. Bucharest: Editura Institutului Cultural Rom^an.

[67] Nuijten,M. (2003) Power, Community and the State: The Political Anthropology of Organisation in Mexico. London and Sterling, VA: Pluto Press.

[68] Otsuka, K., \& Place, F. (2001).Land tenure and natural resource management: A comparative study of agrarian communities in Asia and Africa. Baltimore, London: The John Hopkins University Press.

[69] Pacheco, P. (2009) "Agrarian Reform in the Brazilian Amazon: Its Implications for Land Distribution and Deforestation," World Development, 37(8), 1337-1347.

[70] Patterson, C., (2009), The Paradox of market reform: Pământ and the vicious circle in the Republic of Moldova, ANN.ROUM.ANTHROPOL.46, p.77-91, Bucharest 


\author{
(online) = ISSN $2285-3642$ \\ ISSN-L = $2285-3642$ \\ Journal of Economic Development, Environment and People \\ Volume 2, Issue 1, 2013 \\ URL: http://jedep.spiruharet.ro \\ e-mail: office jedep@spiruharet.ro
}

[71] Peters, P. E. (2009) "Challenges in Land Tenure and Land Reform in Africa: Anthropological Contributions," World Development, 37(8), 1317-1325.

[72] Peluso, N. (1992) Coercing Conservation: The Politics of State Resource Control. Global Environmental Change 3(2), pp. 199-217.

[73] Peluso, N.L., (1992). Rich Forests, Poor People: Resource Control and Resistance in Java. University of California Press, Berkeley, C.A.

[74] Peluso, N.L., (1996). Fruit Trees and Family Trees in an Anthropogenic Forest: Ethics of Access, Property Zones, and Environmental Change in Indonesia. Comparative Studies in Society and History 28, pp. 510548.

[75] Place, F. (2009) "Land Tenure and Agricultural Productivity in Africa: A Comparative Analysis of the Economics Literature and Recent Policy Strategies and Reforms," World Development, 37(8), 1326-1336.

[76] Platteau, J.-P. (1996) 'The Evolutionary Theory of Land Rights as Applied to Sub-Saharan Africa: A Critical Assessment', Development and Change 27(1): 29-86.

[77] Pop-Eleches, G. (2001) 'Romania's Politics of Dejection', Journal of Democracy 12(3): 156-69.

[78] Rabinowicz, E., and J. F. M. Swinnen. (1997). Political economy of privatization and decollectivization of Central and East European agriculture: definitions, issues and methodology. Pages 1-31.inJ. F. M. Swinnen Eds, Political economy of agrarian reform in Central and Eastern Europe. Ashgate, Aldershot.

[79] Ribot, J. (1998) Theorizing Access: Forest Profits along Senegal's Charcoal Commodity Chain. Development and Change 29, pp. 307-341.

[80] Ribot, J.C., \& Peluso, N. (2003).A theory of access.Rural Sociology, 68(2), pp. 153-181.

[81] Rocheleau, D. and L. Ross (1995) 'Trees as Tools, Trees as Text: Struggles over Resources in ZambranaChacuey, Dominican Republic', Antipode 27(4): 407-28.

[82] Rocheleau, D., and D. Edmunds (1997) Women, Men and Trees: Gender, Power and Property in Forest and Agrarian Landscapes. World Development 25(8): 1351-1371.

[83] Shipton, P., \& Goheen, M. (1992). Understanding African land-holding: Power, wealth, and meaning. Africa, 62, 307-325.

[84] Schwartz A.H., (2006). The Politics of Greed: How Privatization Structured Politics in Central and Eastern Europe. Plymouth: Rowman \& Littlefield, INC.

[85] Schwartz, K.Z.S. (2006) "Masters in Our Native Place": The politics of Latvian national parks on the road from Communism to Europe. Political Geography 25, pp. 42-71.

[86] Schwegler A.T., (2008). Take it from the top (down)? Rethinking neoliberalism and political hierarchy in Mexico.American Ethnologist 35(4): 682-700.

[87] Scott J., (1998). Seeing Like a State. How Certain Schemes to improve the Human Condition Have Failed. New Haven and London: Yale University Press.

[88] Scott, J.C., (2005), Afterword to Moral Economies, State Spaces, and Categorical Violence, American Anthropologist, 107 (3), p. 396-402.

[89] Sikor, T. (2003). Thoughts on the Role of the State in Resource Governance, in: The Common Property Resource Digest, No. 64, p. 9,

[90] Sikor, T. (2004), The Commons in Transition: Agrarian and Environmental Change in Central and Eastern Europe, in: Environmental Management, Vol. 34, No. 2, pp. 270-280. 


\author{
(online) = ISSN $2285-3642$ \\ ISSN-L = $2285-3642$ \\ Journal of Economic Development, Environment and People \\ Volume 2, Issue 1, 2013 \\ URL: http://jedep.spiruharet.ro \\ e-mail: office jedep@spiruharet.ro
}

[91] Sikor, T., (2005), Property and Agri-Environmental Legislation in Central and Eastern Europe, Sociologia Ruralis, 45 (3), p. 187-201.

[92] Sikor, T. (2006), Analyzing Community-based Forestry: Local, Political and Agrarian Perspectives, in: Forest Policy and Economics, Vol. 8, No. 4, pp. 339-349,.

[93] Sikor, T. Lund C. , (2009), Access and Property: A Question of Power and Authority, Development and Change, Vol. 40, No. 1, pp. 1-22,.

[94] Sikor, T. and D. Muller (2009) "The Limits of State-Led Land Reform: An Introduction,"

World Development, 37(8), 1307-1316.

[95] Sikor, T., Stahl, J., Dorondel, S. (2009), Negotiating Post-Socialist Property and State: Struggles over Forests in Albania and Romania, Development and Change, Vol. 40, No. 1, pp. 171-193,

[96] Sikor, T., M,ller, D. and J. Stahl, (2009) "Land Fragmentation and Cropland Abandonment in Albania: Implications for the Roles of State and Community in Post-Socialist Land Consolidation," World Development, Volume 37(8), 1411-1423.

[97] Sikor, T., Sturgeon, J., 2004. Postsocialist property relations in Asia and Europe: variations on fuzziness. Conservation and Society 2, $1-17$.

[98] Staddon, C. (2000) 'Restitution of Forest Property in Post-Communist Bulgaria', Natural Resources Forum 24: 237-46.

[99] Staddon, C. (2001) 'Restructuring the Bulgarian Wood-Processing Sector: Linkages Between Resource Exploitation, Capital Accumulation, and Redevelopment in a Postcommunist Locality', Environment and Planning A 33: 607-28.

[100] Stark, D. and L. Bruszt (1998) Post-Socialist Pathways: Transforming Politics and Property in East Central Europe. Cambridge: Cambridge University Press.

[101] Sturgeon, J., Sikor, T. (2004), Postsocialist Property in Asia and Europe - Variations on 'Fuzziness', in: Conservation and Society, Vol. 2, No. 1, pp. 1-17,.

[102] Swinnen, J. F. M. (1997). The choice of privatization and decollectivization policies in Central and Eastern European agriculture: Observations and political economy hypotheses. Pages 363-398.inJ. F. M. Swinnen Eds, Political economy of agrarian reform in Central and Eastern Europe. Ashgate, Aldershot, UK.

[103] Swinnen, J. F. M., A. Buckwell, and E. Mathijs.(1997). Agricultural privatization, land reform and farm restructuring in Central and Eastern Europe.Ashgate, Aldershot, UK 396.

[104] Swinnen, J. F. M., and E. Mathijs. (1997). Agricultural privatization, land reform and farm restructuring in Central and Eastern Europe: A comparative analysis. Pages 333-365.In J. F. M.

[105] Szelenyi, I. (1998). Introduction: a theoretical framework. Pages 1-17.inl. Szelenyi Eds, Privatizing the land: rural political economy in post-communist societies. Routledge, London.

[106] Tangermann, S., and M. Banse.(2000). Central and Eastern European agriculture in an expanding European Union.CAB International Publishing, Wallingford, Connecticut 216.

[107] Tismaneanu, V. and G. Kligman (2001) 'Romania's First Postcommunist Decade: From Iliescu to Iliescu', East European Constitutional Review 10(1) (Internet publication.

http://www1.law.nyu.edu/eecr/vol10num1/features/romaniafirstpostcomdecade.html 


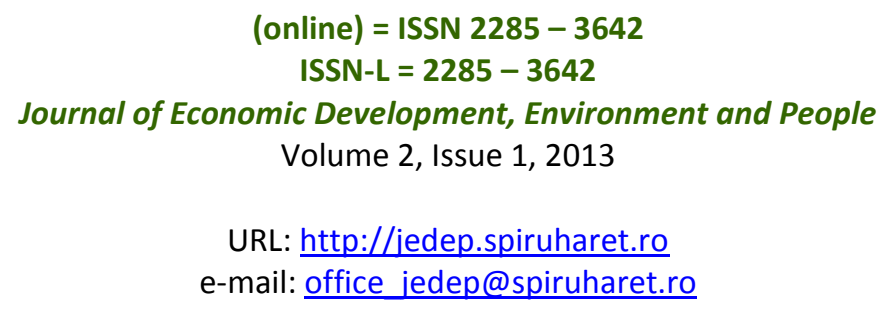

[108] Turnock, D. (1998). Conclusion.Pages 356-400.inD. Turnock Eds, Privatization in rural Eastern Europe: the process of restitution and restructuring. Studies of Communism in Transition.Edward Elgar, Cheltenham, UK.

[109] Upton, C. (2009) "Custom and Contestation: Land Reform in Post-Socialist Mongolia," World Development, 37(8), 1400-1410.

[110] Vandergeest, P., Peluso, N.L., (1995). Territorialization and State Power in Thailand.Theory and Society 24, pp. 385-426.

[111] Verdery K., (1999). Fuzzy property: Rights, Power, and Identity in Transylvania's decollectivization. In: M. Burawoy and K. Verdery (Eds.). Uncertain Transition.Ethnographies of Change in thePostsocialist World.53-81. Lanham Boulder New York Oxford: Rowman \& Littlefield Publishers Inc.

[112] Verdery K., (2002). Whither postsocialism? In: C.M. Hann (ed.). Postsocialism. Ideals, ideologies and practices in Eurasia. Pp. 15-22. London and New York: Routledge.

[113] Verdery K., (2003). The Vanishing Hectare.Property and Value in Postsocialist Transylvania. Ithaca and London: Cornell University Press.

[114] Verdery, K. (1996) What Was Socialism? And What Comes Next? Princeton, NJ: Princeton University Press.

[115] Verdery, K. (2004) 'The Obligations of Ownership: Restoring Rights to Land in Postsocialist Transylvania', in K. Verdery and C. Humphrey (eds) Property in Question. Value Transformation in the Global Economy, pp. 139-59. Oxford and New York: Berg.

[116] Verdery, K. (2004). 'The Property Regime of Socialism', Conservation and Society 2(1): 189-98.

[117] von Benda-Beckmann, K. (1981) 'Forum Shopping and Shopping Forums: Dispute Processing in a Minangkabau Village in West Sumatra', Journal of Legal Pluralism 19: 117-59.

[118] Weber, M. (1976) [1922] Wirtschaft und Gesellschaft: Grundriss der Verstehenden Soziologie (Economy and Society: An Outline of Interpretive Sociology). T"ubingen: J.C.B. Mohr.

[119] Wegren, S. K. (1998). Land reform in the former Soviet Union and Eastern Europe. London: Routledge. 